\title{
The Application of Probiotic to Increase Growth, Body Composition, and Feed Efficiency on Catfish (Clarias sp.)
}

\author{
Achmad Noerkhaerin Putra ${ }^{1,2^{*}}$ \\ ${ }^{1}$ Department of Fisheries \\ Faculty of Agriculture \\ University of Sultan Ageng Tirtayasa \\ ${ }^{2}$ Indonesia Center of Execelenc for Food \\ Security (I-CEFORY), UNTIRTA (Local Food \\ Innovation), \\ Jalan Raya Jakarta KM 04 Pakupatan Serang \\ 42124, Banten, Indonesia \\ *e-mail: putra.achmadnp@untirta.ac.id \\ Dodi Hermawan \\ Department of Fisheries \\ Faculty of Agriculture \\ University of Sultan Ageng Tirtayasa \\ Jalan Raya Jakarta KM 04 Pakupatan Serang \\ 42124, Banten, Indonesia \\ e-mail: dodi_hermawan78@untirta.ac.id
}

\author{
Mustahal \\ Department of Fisheries \\ Faculty of Agriculture \\ University of Sultan Ageng Tirtayasa \\ Jalan Raya Jakarta KM 04 Pakupatan \\ Serang 42124, Banten, Indonesia \\ e-mail:mustahal13@gmail.com
}

\author{
Mas Bayu Syamsunarno \\ Department of Fisheries \\ Faculty of Agriculture \\ University of Sultan Ageng Tirtayasa \\ Jalan Raya Jakarta KM 04 Pakupatan \\ Serang 42124, Banten, Indonesia \\ e-mail: masbyu@gmail.com
}

\begin{abstract}
For 45 days, research was conducted to evaluate the administration of probiotic Bacillus NP5 to increase growth, body composition, and feed efficiency on catfish (Clarias sp.). This research was carried out with 3 different treatment of Bacillus NP5 probiotic doses $(0,0.5$ and $1 \%$ probiotic) and 3 replications. The result showed that the value of the daily growth rate significantly showed the highest value $(P<0.05)$ in $1 \%$ probiotic $(11.32 \%)$, followed by $0.5 \%$ probiotic $(9.20 \%)$ and control $(8.20 \%)$. The value of protein and lipid composition was significantly in $1 \%$ probiotic $(14.24 \%, 5.49 \%$, respectively) than the other treatment. The administration of probiotic Bacillus NP5 not affect to water quality of catfish.
\end{abstract}

Keywords: Body composition, feed efficiency, growth, probiotic

\section{INTRODUCTION}

Catfish is a popular freshwater fish commodity in Indonesia. The ministry of marine and fisheries of Indonesia [1] reported that catfish was the second largest commodity with 19.604.260 tons' production in 2017. However, the low of feed efficiency is one of the problems in the intensive cultivation of catfish system. In addition, feed is one of the biggest cost component in aquaculture, which is about $40-60 \%$ of total production costs [2]. [3] noted that only $20-30 \%$ of feed are assimilated in fish biomass, and the remaining for about $70-80 \%$ of the feed will be accumulated in the water body as uneaten feed and excretion products (ammonia). Ammonia is toxic to fish and at high levels can cause death [4].

One effort that can be applied to improve feed efficiency is the application of probiotic in fish feed. According to [5], probiotic is live micro-organisms which have positives effect on their host by improving feed efficiency or increasing feed digestive enzyme [6], by ensuring increase response immune [7], by improving water quality [8]. The administration of Bacillus NP5 as probiotic has been reported could enhance growth performance of tilapia $[9,10]$ and Dumbo catfish [11]. The supplementation of Bacillus NP5 also reported improve response immune of white shrimp [12] and catfish [13]. [14] noted that Bacillus NP5 is probiotic bacteria from digestive of tilapia. There are 7 steps of selection to obtain Bacillus NP5, namely: amylolytic test, bacterial growth test, resistant on acid and alkali test, activity of antagonistic, adhesion test, pathogenic test, and feeding trial test. The purpose of this study is to evaluate the administration of probiotic Bacillus NP 5 to increase growth, body composition, and feed efficiency on catfish (Clarias sp.).

\section{MATERIALS AND METHODS}

\section{A. Preparation of Probiotic and Feed}

At temperature of $29^{\circ} \mathrm{C}$ for 18 hours (exponential phase of Bacillus NP5), Bacillus NP5 were cultured on agar medium (trypticase soy broth). Then, culture of Bacillus NP5 was centrifuged at speed of $1000 \mathrm{rpm}$ for 10 minutes to harvest probiotic bacteria. The commercial feed (protein of $33.95 \%$, lipid of $7.73 \%$, ash of $9.9 \%$, fibre of $4.16 \%$, nitrogen-free extract of $44.25 \%$ and moisture of $6.49 \%$ ) was used in the present study. Probiotics (mixed with $2 \%$ yolk egg according to [9]) were added at different doses into the feed, i.e. $0 \%$ probiotic (control), $0.5 \%$ probiotic, and $1 \%$ probiotic $(\mathrm{g} / 100 \mathrm{~g})$ and 3 replications. 


\section{B. Experimental Design}

This research was conducted at Laboratory of Aquaculture, University of Sultan Ageng Tirtayasa for 45 days. The initial weight of juvenile of catfish is $9.02 \pm 0.29 \mathrm{~g}$. Catfish obtained from Ary Farm, Serang, Indonesia. Catfish was reared in 12 tanks with volume of $60 \mathrm{~L}$ (20 fish/tank) and they were acclimatized for 7 days. Feed were given to catfish three times $(08.00,12.00$, and 16.00) with satiations. The maintain water quality was conducted every 3 days by water replacement of tank (50\% of total volume).

\section{Measurement of Growth, Body Composition and Water Quality.}

Dissolved oxygen and $\mathrm{pH}$ were measured weakly, while water temperature was measured every day. At the end trial, catfish were weighed and 5 fish from each tank were used for proximate analyses. Fishwere analyzed (protein, lipid, moisture, nitrogen-free extract, ash, fibre and moisture) referring to [15]. Feed intake, specific growth rate, feed efficiency and survival rate were measured in accordance [16], by equations:

$\mathrm{Ft}$

$$
\mathrm{FI}(\%)=\mathrm{Fo}-
$$

Where FI is feed intake, Fo is total feed at the beginning, andFt is total feed at the end.

$$
\operatorname{DGR}\left(\% \text { day }^{-1}\right)=100 \times\left(\frac{\mathrm{Wt}-\mathrm{Wo}}{\mathrm{t}}\right)
$$

Where DGR is daily growth rate, Wt is final body weight, Wo is initial body weight, and $t$ is days.

$$
\mathrm{FE}(\%)=100 \times\left(\frac{\mathrm{W}}{\mathrm{F}}\right)
$$

Where FE, W, F were feed efficiency, weight gain and feed consumption, respectively.

$$
\operatorname{SR}(\%)=100 \times\left(\frac{\mathrm{Nt}}{\mathrm{No}}\right)
$$

Where SR is survival rate, $\mathrm{Nt}$ is total individual at the end and No is total individual at the initial.

\section{Statistical Analyses}

The value of feed intake, specific growth rate, feed efficiency, survival rate, and body composition were analyzed using the Statistical Package for the Social Sciences (SPSS) program for Windows (v. 16.0). the significant data were compared by Duncan of multiple comparisons. All data of water quality were analyzed descriptively.

\section{RESULT AND DISCUSSION}

\section{A. Growth and Survival Rate}

Growth parameter and survival rate in this study was presented in Table 1. No significant effect $(\mathrm{P}>0.05)$ was obtained in feed intake for all treatments (control: $479.10 \pm 48.3$ g, $0.5 \%$ probiotic: $472.24 \pm 42.3 \mathrm{~g}$, and $1 \%$ probiotic: $544.78 \pm 21.3 \mathrm{~g})$. Feed intake shows the amount of feed consumed by fish [17]. Its value related to feed palatability [18]. [19] noted that nutrient and toxin content in the feed are factor affecting feed palatability. In the present study, feed intake was found no different among all treatments. This result showed that the addition Bacillus NP 5 in the feed not influenced on feed palatability. The similar result has been reported by [20], the administration of Lactococcus lactis and Enterococus faecium

\begin{tabular}{|c|c|c|c|}
\hline Treatments & Control & $\begin{array}{l}0.5 \% \\
\text { probiotic }\end{array}$ & $\begin{array}{l}1 \% \\
\text { probiotic }\end{array}$ \\
\hline \multicolumn{4}{|l|}{ Parameters* } \\
\hline Feed intake (g) & $479.10 \pm 48.3$ & $472.24 \pm 42.3$ & $544.78 \pm 21.3$ \\
\hline $\begin{array}{l}\text { Daily growth rate } \\
\left(\% \text { day }^{-1}\right)\end{array}$ & $8.20 \pm 0.55^{\mathrm{a}}$ & $9.20 \pm 1.61^{\mathrm{a}}$ & $11.32 \pm 0.8^{\mathrm{b}}$ \\
\hline $\begin{array}{l}\text { Feed Efficiency } \\
(\%)\end{array}$ & $77.20 \pm 3.23^{\mathrm{a}}$ & $87.35 \pm 8.78^{\mathrm{ab}}$ & $93.44 \pm 4.27^{\mathrm{b}}$ \\
\hline Survival Rate (\%) & $96.67 \pm 5.77$ & $96.67 \pm 2.89$ & $100 \pm 0.00$ \\
\hline
\end{tabular}
not effect on feed intake of grouper Epinephelus coioides.

TABEl I. GROWTH PARAMETERS AND SuRVIVAl RATE OF CATFISH With DiFFERENT PROBIOTIC DOSES IN THE FEED.

Daily growth rate was significant highest $(\mathrm{P}<0.05)$ in $1 \%$ probiotic $\left(11.32 \pm 0.8 \%\right.$ day $\left.^{-1}\right)$, but no significant differences between control $\left(8.20 \pm 0.55 \%\right.$ day $\left.^{-1}\right)$ and $0.5 \%$ probiotic $\left(9.20 \pm 1.61 \%\right.$ day $\left.^{-1}\right)$. Furthermore, the value of feed efficiency was significantly increased in $1 \%$ probiotic $(93.44 \pm 4.27 \%$ ) compared control $(77.20 \pm 3.23 \%)$ and there are no significant between control and $0.5 \%$ probiotic $(87.35 \pm 8.78 \%)$. This result is supported by [21], dietary probiotic lactobacillus acidophilus of African catfish feed was increased growth and feed conversion ratio than control. [22] noted that application of Bacilli (Bacillus subtilis and Bacilus licheniformis) can improve growth performance and feed efficiency of whitele shrimp (Litopeaeus vannamei)postlarvae. Effect probiotic also has reported can increase several commodities of aquaculture, namely on tilapia with probiotic cocktail [23], on freshwater prawn macrobrachium rosenbergii with Lactobacillus sporogenes, Bailus subtilis and yeast asprobiotic [24], on rohu, Labeo rohita with probiotic Geotrichum candidum [25].

Probiotic can produce digestive enzyme in host digestive tract $[6,26,27]$. [11] has been reported that supplementation of Bacillus NP5 as probiotic could increase protease, lipase and amylase activity in digestive tract of Dumbo catfish. At the present study, the high value of daily growth rate in $1 \%$ probiotic might due to probiotic can increase the population of bacteria in digestive tract. This will increase of feed absorption so that catfish in $1 \%$ probiotic treatment increased. The study of [9] was found that the addition of probiotic can improve the population 
of microbiota and digestive enzyme in digestive tract of tilapia. In the present study, we obtained no significant different between control and $0.5 \%$ probiotic. That is probably due to the low dose of $0.5 \%$ probiotic treatment, so that administration probiotic cannot increase daily growth rate of catfish in this treatment. The similar result has investigated by [28] on white shrimp with application Bacillus into feed. He noted that the low doses ofBacillus not influence on growth of white shrimp.

In our study, we found that there was no significant different ( $P>0.05)$ in survival rate. The value of survival rate in control of $96.67 \pm 5.77 \%, 0.5$ probiotic of $96.67 \pm 2.89 \%$ and $1 \%$ probiotic of $100 \pm 0.00 \%$. this result indicates that administration Bacillus NP5 as probiotic did not effect on fish health of catfish. Similar effect has been reported by [28], supplementation of Bacillus in the feed showed not significant different on survival rate of white shrimp Litopenaeus vannamei. [29] also reported that administration of the mixed probiotics (Bacillus subtilis, $B$. licheniformis and Enteroccus faecium) was found not influence on survival rate of rainbow trout (Oncorhynchus mykiss Wabaum).

\section{B. Body Composition}

The beneficial effects of Bacillus genus as probiotic on aquaculture have been observed, such asBacillus spp. [26, 30, 31], Bacillus subtilis [22, 32, 33], Bacillus NP5 [10,12,13], Bacillus sp. [34], Bacillus licheniformis [22], Bacillus cereus [35], Bacillus mycoides [36], Bacillus coagulans [37]. Effects of administration of probiotic Bacillus NP5 was showed Table 2.

TABLE II. BODY COMPOSITION OF CATFISH WITH DIFFERENT PROBIOTIC DOSES IN THE FEED.

\begin{tabular}{llll}
\hline Treatments* & Control & $\begin{array}{l}\mathbf{0 . 5 \%} \\
\text { probiotic }\end{array}$ & $\begin{array}{l}\mathbf{1} \% \\
\text { probiotic }\end{array}$ \\
\hline Parameters & & & \\
Crude protein (\%) & $10.34 \pm 0.06^{\mathrm{a}}$ & $10.08 \pm 0.04^{\mathrm{a}}$ & $14.24 \pm 0.34^{\mathrm{b}}$ \\
Crude lipid (\%) & $5.02 \pm 0.04^{\mathrm{a}}$ & $5.08 \pm 0.11^{\mathrm{a}}$ & $5.49 \pm 0.13^{\mathrm{b}}$ \\
Fibre (\%) & $0.32 \pm 0.03$ & $0.29 \pm 0.01$ & $0.32 \pm 0.01$ \\
Nitrogen-free & $0.40 \pm 0.11$ & $0.82 \pm 0.20$ & $0.52 \pm 0.16$ \\
extract (\%) & & & \\
Ash (\%) & $2.98 \pm 0.68$ & $2.57 \pm 0.14$ & $3.87 \pm 0.04$ \\
Moisture (\%) & $80.94 \pm 0.57^{\mathrm{b}}$ & $81.16 \pm 0.03^{\mathrm{b}}$ & $76.56 \pm 0.42^{\mathrm{a}}$ \\
\hline
\end{tabular}

* The value in the same row withdifferent superscript are significantly different $(\mathrm{p}<0.05)$.

The result showed that protein composition was significantly increased in $1 \%$ probiotic $(14.24 \pm 0.34 \%)$. In the present study was observed no different $(\mathrm{P}>0.050$ between control and $0.5 \%$ probiotic $(10.34 \pm 0.06 \%, 10.08 \pm 0.04 \%)$ in protein composition.The same result was found in lipid composition, the highest value of lipid composition was observed in $1 \%$ probiotic $(5.49 \pm 0.13 \%)$ and no different $(\mathrm{P}>0.05)$ between control $(5.02 \pm 0.04 \%)$ and $0.5 \%$ probiotic $(5.08 \pm 0.11 \%)$. In the present study no significant difference $(\mathrm{P}>0.05)$ was showed in the data of fibre, nitrogen-free extract and ash.Body composition at the present study in in agreement with the result of [22], who noted that the addition of Bacilli (Bacillus subtilis and Bacillus licheniformis) in the feed had higher on crude protein and crude lipid than control of whiteleg shrimp (Litopenaeus vannamei) postlarvae. [37] also reported that supplementation of probiotic can improve body composition of white shrimp. Body compositions are related to growth performance of fish. Therefore, the highest value of crude protein and crude lipid on $1 \%$ probiotic treatment might due to the value of daily growth rate on this treatment.

\section{Water Quality}

The role of probiotic on water quality in aquaculture has been reported by researchers, such ason nile tilapia [38], larvae shrimp (Penaeus vannamei) [39], blue swimming crab, Portunus pelagicus (Linnaeus, 1758) [40], and white shrimp (Litopenaeus vannamei) [41]. The range water quality in this study presented Table 3 .

TABLE III. WATER QUALITY OF CATFISH WITH DIFFERENT PROBIOTIC DOSES IN THE FEED.

\begin{tabular}{|c|c|c|c|}
\hline Treatments & Control & $\begin{array}{l}0.5 \% \\
\text { probiotic }\end{array}$ & $\begin{array}{l}1 \% \\
\text { probiotic }\end{array}$ \\
\hline \multicolumn{4}{|l|}{ Parameters } \\
\hline Temperature $\left({ }^{\circ} \mathrm{C}\right)$ & $27.13-28.63$ & $27.17-28.80$ & $27.13-28.63$ \\
\hline $\begin{array}{l}\text { Dissolved oxygen } \\
(\mathrm{mg} / \mathrm{L})\end{array}$ & $5.30-7.10$ & $5.67-7.23$ & $5.70-7.13$ \\
\hline $\mathrm{pH}$ & $5.70-7.97$ & $5.80-7.93$ & $5.77-7.94$ \\
\hline
\end{tabular}

Temperature is important factor which can influence in fish metabolism and fish physiological [42]. The result show that the range temperature of control of $27.13-28.63^{\circ} \mathrm{C}, 0.5 \%$ probiotic of $27.17-28.80^{\circ} \mathrm{C}$ and $1 \%$ probiotic of $27.13-28.63{ }^{\circ} \mathrm{C}$. This is indicated that temperature in this study is in accordance with the catfish culture. According to [43], the best temperature of catfish rearing is $27-30{ }^{\circ} \mathrm{C}$. Oxygen is the limiting factor for water organism. The result show that the value of dissolved oxygen is $5.30-7.10 \mathrm{mg} / \mathrm{l}$ in control, $5.67-7.23 \mathrm{mg} / \mathrm{L}$ in $0.5 \%$ probiotic, and $5.70-7.13 \mathrm{mg} / \mathrm{L}$ in $1 \%$ probiotic. This value within the range suitable for catfish farming. The range of dissolved oxygen for catfish culture is $>3 \mathrm{mg} / \mathrm{L}$ [43]. The role of $\mathrm{pH}$ on the fish culture is a measure the acidity of water. The range of $\mathrm{pH}$ for catfish culture is 6,50 - 8,50 [42]. In this study, the range of $\mathrm{pH}$ is 5.707.97 which indicates the value within the range of suitable for catfish culture.

\section{CONCLUSION}

The administration of Bacillus NP5 as probiotic show the best result on daily growth rate, feed efficiency, and protein and lipid composition of catfish. the value of daily growth rate was significantly highest $(\mathrm{P}<0.05)$ in $1 \%$ probiotic $(11.32 \%)$, followed by $0.5 \%$ probiotic $(9.20 \%)$ and control $(8.20 \%)$. The value of protein and lipid composition was significantly in $1 \%$ probiotic $(14.24 \%, 5.49 \%$, respectively) than the other treatment.

\section{ACKNOWLEDGMENTS}

This research was supported by funds fromislamic development bank with scheme of Research Grand IsDB- 
Untirta (Program Penelitian Dasar Unggulan Perguruan Tinggi). Contract number: B/60/UN43.9/PT.01.03/2019.

\section{REFERENCES}

[1] The ministry of marine and fisheries. 2019. Marine and fisheries in numbers (in Indonesian). Accessed on 2019, $10^{\text {th }}$ July. fromhttps://kkp.go.id/setjen/satudata/artikel/9669-kelautan-danperikanan-dalam-angka-2018-telah-terbit.

[2] Tacon AGJ \& Metian M. 2008. Global overview on the use of fish meal and fish oil in indusstrially compounded aquafeed: Trends and future prospects. Aquaculture 285: 146-158.

[3] Avnimelech Y \& Ritvo. 2003. Shrimp and fish pond soils: processes and management. Aquaculture 220: 549-567.

[4] Boyd CE \& Mcnevin AA. 2014. Aquaculture Resource Use, and The Environment. Canada: Wiley Blackwell. 377 pp.

[5] Verchuere L, Rombaut G, Sorgeloos P, Verstrate W. 2000. Probiotic bacteria as biological control agents in aquaculture. Microbiology and Molecular Biology Reviews 64: 655-671.

[6] Ziaei-Nejad S, Rezaei MH, Takami GA, Lovett DL, Mirvaghefi AR, Shakouri M. 2006. The effect of Bacillus spp.. Bacteria used as probiotics on digestive enzyme activity, survival and growth in the Indian white shrimp Fenneropenaeus indicus. Aquaculture 252: 516-524.

[7] Newaj-Fyzul A, Al-Harbi AH, Austin B. 2014. Review: developments in the use of probiotics for disease control in aquaculture. Aquaculture 431: $1-11$.

[8] Perez-Sanchez T, Ruiz-Zarzuela I, Blas ID, Balcazar JL. 2013. Probiotics in aquaculture: a current assessment. Reviews in Aquaculture 5: 1-14.

[9] Putra AN, Widanarni, Utomo NBP. 2015. Growth performance of tilapia Oreochromis niloticus fed with probiotic, prebiotic and synbiotic in diet. Pakistan Journal of Nutrition 14: 263-268.

[10] Utami DAS, Widanarni, Suprayudi MA. 2015. Quality of dried Bacillus NP5 and its effect on growth performance of tilapia Oreochromis niloticus. Pakistan Journal of Biological Sciences 18: 88-93.

[11] Putra AN and Romdhonah Y. 2019. Effects of dietary Bacillus NP5 and sweet potato extract on growth and digestive enzyme activity of dumbo catfish, Clarias sp.. Jurnal Akuakultur Indonesia 18 (1): 80-88.

[12] Widanarni, Yuhana M, Muhamad A. 2014. Bacillus NP5 improves growth performance and resistance against infectious myonecrosis virus in white shrimp Litopenaeus vannamei. Indonesian Journal of Marine Sciences 19: 211-218.

[13] Tamamdusturi R, Widanarn, Yuhana M. 2016. Administration of microencapsulated probiotic Bacillus sp. NP5 and prebiotic mannan oligosaccharide for prevention of Aeromonas hydrophila infection on Pangasianodon hypopthalmus. Journal of Fisheries and Aquatic Science 11: 67-76.

[14] Putra AN and Widanarni. 2015. Screening of amylolytic bacteria as candidates of probiotics in tilapia Oreochromis sp.. Research Journalof Microbiology 10: 1-13.

[15] AOAC (Association of Official Analytical Chemists). 1995. Official Methods of Analysis. 16th ed Volume II: Maryland.

[16] Huisman EA. 1987. Principles of Fish Production. Department of Fish Culture and Fisheries, Wageningen Agriculture University, Wageningan, Netherland. 170p.

[17] National Research Council. 2011. Nutrient requirements of fish and shrimp. In: The National Academies Press, Washington, DC. 376 pp.

[18] Harver \& Hardy. 2002. Fish Nutrition: Bionergetics. Academic Prees: California USA.

[19] Tantiakitti C. 2014. Review article: Feed palatability and the alternative potein sources in shrimp feed. Songklanakarin Journal of Science and Technology 36 (1): 51-55.

[20] Sun Y-Z, Yang H-L, Ma R-L, Song K, Li J-S. 2012. Effect of Lactococcus lactis and Enterococcus faecium on growth performance, digestive enzymes and immune response of grouper (Epinephelus coioides). Aquaculture Nutrition 18 (3): 281-289.
[21] Al-Dohail MA, Hashim R. \& Aliyu-Paiko M. 2009. Effects ofthe probiotic, Lactobacillus acidophilus, on the growth performance,haematology parameters and immunoglobulin concentrationin African Catfish (Clarias gariepinus, Burchell 1822)fingerling. Aquaculture Research40: 1642-1652.

[22] Madani NSH, Adorian TJ, Farsani HG, Hoseinifar SH. 2018. The effects of dietary probiotic Bacilli (Bacillus subtilis and Bacillus licheniformis) on growth performance, feed efficiency, body composition and immune parameters of whiteleg shrimp (Litopenaeus vannamei) postlarvae. Aquaculture Research 49 (5): 1926-1933.

[23] Ayyat MS, Labib HM, Mahmoud HK. 2014. A probiotic cocktail as a growth promoto in nile tilapia (Oreochromis nilotius)Journal of Applied Aquaculture 26: 208-215.

[24] Seenivasan C, Bhavan PS, Radhakrishnan S, Muralisankar T. 2012. Effects of probiotic on survival, growth and biochemical constituents of freshwater prawn macrobrachium rosenbergii. Turkish Journal of Aquatic Sciences 12: 331-338.

[25] Ibrar M, Zuberi A, Amir I, Imran M, Noor Z. 2017. Effect of probiotic Geotrichum candidum on early rearing of Labeo rohita (Hamilton, 1822). Turkish Journal of Aquatic Sciences 17: 1263-1270.

[26] Ziaei-Nejad S, Rezaei MH, Takami GA. 2006. The effect of Bacillus spp. bacteria used as probiotics on digestive enzyme activity, survival and growth in the indian white shrimp (Fenneropenaeus indicus). Aquaculture, 252: 516-524.

[27] Zhou XX, Wang YB, Fen LW. 2009. Effect of probiotic on larvae shrimp (Penaeus vannamei) based on water quality, survival rate and digestive enzyme activities. Aquaculture, 287: 349-353.

[28] Yu M-C, Li Z-J, Lin H-Z, Wen G-L, Ma S. 2008. Effects of dietary medicinal herbs and Bacillus on survival, growth, body composition, and digestive enzyme activity of the white shrimp Litopnaeus vannamei. Aquaculture International 17: 377-384.

[29] Merrifield DL, Bradley G, Baker RTM, Davies SJ. 2010. Probiotic applications for rainbow trout (Oncorhynchus mykiss Walbaum) II. Effects on growth performance, feed utilization, intestinal microbiota and related heath criteria postantibiotic treatment. Aquaculture Nutrition 16: 496-503.

[30] Cha J-H, Rahimnejad S, Yang S-Y, Kim K-W, Lee K-J. 2013. Evaluations of Bacillus spp. as dietary additives on growth performance innate immunity and disease resistance of olive flounder (Paralichthys olivaceus) against Streptococcus iniae and as water additives. Aquaculture 402-403: 50-57.

[31] Daniles CL, Merrifield DL, Boothroyd DP, Davies SJ, Factor JR, Arnold KE. 2010. Effect of dietary Bacillus spp. and mannan oligogasaccharides (MOS) on European lobster (Homarus gammarus L.) larvae growth performance, gut morphology and gut microbiota. Aquaculture 304 (1-4) 49-57.

[32] Hassan MS, Soltan MA, Mohammady EY, Elashry MA, El-Haroun ER, Davies SJ. 2018. Growth and physiological responses of nile tilapia, Oreochromis niloticus fed dietary fermented sunflower meal inoculated with Saccharomyces cerevisiae and Bacillus subtilis. Aquaculture 495: 592-601.

[33] Ai Q, Xu H, Mai K, Xu W, Wang J, Zhang W. 2011. Effects of dietary supplementation of Bacillus subtilis and fructooligosaccharide on growth performance, survival, nonspecific immune responses and disease resistance of juvenile large yellow croaker, Larimichthys. Aquaculture 317 (1-4): 155-161.

34] Yanbo W \& Zirong X. 2006. Effect of probiotic for common carp (Cyprinus carpio) based on growth performance and digestive enzyme activities. Aquaculture 127: 283-292.

[35] Wee wC, Mok CH, Romano N, Ebrahimi M, Natrah I. 2018. Dietary supplementation use of Bacillus cereus as quorum sensing degrades and their effects on growth performance and response of Malaysian giant river prawn macrobrachium rosenbergii juvenile towards Aeromonas hydrophila. Aquaculture Nutrition 24 (6): 1804-1812.

[36] Ambas I, Fotedar R, Buller N. 2017. Synbiotic effect of bacillus mycoides and organic selenium on immunity and growth of marron, Cherax cainii (Austin, 2002). Aqaculture Research 48 (6): 2729-2740. 
[37] Wang Y. 2011. Use of probiotic bacillus coagulans, Rhodopseudomonas palustris and Lactobacillus asidophilus as growth promotors in grass carp (Ctenpharyngodon idella) fingerlings. Aquaculture nutritions 17 (2): e372-e378.

[37] Wang YB, Fu LL, Lin J. 2012. Probiotic (Bacillus coagulans) cells in the diet benefit the white shrimp Litopenaeus vannamei. Journal of Shellfish Research 31 (3):855-860.

[38] Elsabagh M, Mohamed R, Moustafa EM, Hamza A, Farrag F, Decamp O, Dawood MAO, Eltholth M. 2018. Assessing the impact of Bacillus strains mixture probiotic on water quality, growth performance, blood profile and intestinal morphology of Nile tilapia, Oreochromis niloticus. Aquaculture Nutrition 24 (6): 1613-1622.

[39] Zhou X-X, Wang Y-B, Li W-F. 2009. Effect of probiotic on larvae shrimp (Peeus vannamei) based on water quality, survival rate and digestive enzyme activities. Aquaculture 287: 349-353.

[40] Talpur AD, Ikhwanuddin MHD, Abdullah MDD, Bolong A-MA. 2017 Indigenous Lactobacillus plantarum as probiotic for larviculture of blue swimming crab, Portunus pelagicus (Linnaeus, 1758) effects on survival, digestive enzyme activities and water quality. Aquaculture 416-417: 173178.

[41] Nimrat S, Suksawat S, Boonthai T, Vuthiphandchai. 2012. Potential Bacillus probiotics enhance bacterial numbers, water quality and growth during early development of white shrimp (Litopenaeus vannamei). Veterinary Microbiology 159 (3-4): 443-450.

[42] Boyd CE, \& Massaut L. 1999. Risks associated with the use of chemicals in pond aquaculture. Aquacultural Engineering, 20, 113-132.

[43] Gross A, Boyd CE, and Wood CW. 2000. Nitrogen Transformations and Balanced in Channel Catfish Ponds. Aquacultural Engineering. 24:1-14. 